\title{
HEALTH AND HYGIENE PRACTICES AMONG SCHOOL CHILDREN IN MANGALORE CITY
}

\author{
Prof. AshaRai. M. G. \\ Ph.D Research Scholar, Associate professor \\ HOD. Home Science, Besant Women's College. Mangalore, India \\ Dr. Mamatha .B, \\ Research Guide, Associate professor, \\ Department of Resource Management, \\ Smt. V.H.D. Central Institute of Home Science, Bangalore, India
}

\begin{abstract}
Health and hygiene pose grave problems in the entire world. Globally, billions of people do not have access to improved health and hygiene. Sanitation is least cared for. So, this study is undertaken with the objectives, to find the practices of health and hygiene among school children in Mangalore city and to compare the practices on health and hygiene between Government, Private and Aided school children.

Tools used for the study were Survey method and Questionnaire. Children in the age range of 10-12 years were selected for the study. Sixteen schools, 8 from north and 8 from south were taken for the study. Questionnaires were distributed to 820 respondents, i.e. 183 Government, 309 Aided and 328 Private school children to elicit information regarding their practices on health and hygiene. Questions were explained to them clearly during the study. The opinions collected by using the questionnaire were scored and tabulated. It was seen from the finding that mean practice scores were found highest in Private school (74.2\%) when compared to Government school (55.8\%) and Aided school (55.4\%) respondents. The data wasanalyzed statistically by using the $F$ test and found that there was a highly significant difference between different types of school and the mean practice score on health and hygiene ( $F=733.32 * *)$.
\end{abstract}

Keywords: Practice of health hygiene, Government school, Aided school, Private school.

Cite this Article: Prof. AshaRai.M.G. and Dr. Mamatha .B, Health and Hygiene Practices Among School Children in Mangalore City,. International Journal of Management, 10 (1), 2019, pp. 60-64.

http://iaeme.com/Home/issue/IJM?Volume=10\&Issue $=1$ 


\section{INTRODUCTION}

It is a known practice, especially in India and other under developed countries that sanitation is the least that gets priority. Many defecate in the open air. Poor hand washing practices and limited access to sanitation facilities perpetuate the transmission of disease-causing germs. The inadequacy of health and hygiene in India has prompted the Prime Minister to promote a slogan to the People that "Swacch Bharat, Swasth Bharat" meaning Clean India is a healthy India.

With the kind of health risks that are posed to the human race today, it has become vital to stay as hygienic as possible. Considering the kind of weather conditions and harsh climate that India faces, it is all the more important that we stay as hygienic as possible and teach our children these good habits.

A large fraction of the world's illness and death is attributable to communicable diseases. Poor hygiene practices and inadequate sanitary conditions play major roles in the increased burden of communicable diseases within developing countries (Vivaset al. 2010).

School health is an important branch of community health. School health services are an economical and powerful means of raising community health. In school child is vulnerable to stress, tension and endangerment of group life because all children are not the same and comes from different socioeconomic and cultural background and with different immunity status. The child is quite vulnerable at this growing age and hence become easy victims of many non-communicable diseases such as dental caries, anaemia, visual and hearing defects (Asghar, 2017).

This study is undertaken by the investigator to find the practices on health and hygiene among school children in Mangalore city.

\section{METHODOLOGY}

\subsection{Aim}

The study aimed to explore practices of health among school going children aged 10-12 years in Mangalore city.

\subsection{Objectives}

1. To find health and hygiene practices among school children in Mangalore city

2. To compare the health and hygiene practices between Government, Private and Aided school children

\subsection{Research Design}

The researcher referred the DPI (Directorate of public instruction) to identify and shortlist schools in Mangalore city. Selection was done keeping in mind the type of school that is Government, Aided and Private and two zones of Mangalore city namely north and south. Eight schools from the north and eight schools from the south zone a total of 16 schools were selected. In the selected 16 schools questionnaires were distributed to the children aged 10-12 years studying in V, VI,VII standards. A total of 820 of which 183 Government, 309 Aided and 328 Private school children were surveyed. The questionnaire consists of background information of the respondents and specific data includes questions related to knowledge on health and hygiene. Questions were explained to them clearly during the study. The opinions collected by using the questionnaire were scored and tabulated 


\section{ANALYSIS OF THE DATA}

\subsection{Background information}

A sample of 820 children aged 10-12 years were taken for the study. They were identified from Government, Aided and Private schools from the North and South zones of Mangalore city.

It was found that majority of the students belonging to Government and Private schools were in the age of 12 years followed by 11 years and 10 years. It was found that most of the students of Aided school were in the age of 12 years followed by 10 years and 11 years.Majority of the students belonging to Government and Aided school were studying in the class VII followed by class VI and class V. Further it was also found that most of the students of the Private school were studying in class VI followed by VII and V class.

Girl students were more when compared to boys in Government, Aided and Private school.

Higher percentage of the respondents belonging to Government, Private and Aided were from nuclear families.

Most of Government and Aided school children's mother tongue was Kannada followed by Tulu. Further it was also found that Tulu speaking respondents were more in Private schools than in Aided and Government schools. It was also found that respondents' fathers belonging to Private school were better educated when compared to respondents' fathers from Aided and Government school

It was found that mothers of the respondents of Private school were better educated when compared to Aided and Government school. Higher percentages of the respondents' fathers were commission agents, brokers. Most of the respondent's mothers were housewives among Government,Aided andPrivate school.The income distribution of Parents from Private and Aided school were found to be more as compared to respondents from Government school. Majority of the respondents of Aided school, Government and Private school were malnourished.It was found that majority of the respondents eat sometimes outside food among Private Aided and Government school respondents. Majority of the respondents get information on health and hygiene from their schools, television and from doctors.

TABLE 1 Overall Mean scores of Respondents on Practice of Health and Hygiene by Type of school $\mathrm{N}=820$

\begin{tabular}{|c|c|c|c|c|c|c|c|c|}
\hline \multirow[b]{2}{*}{ Response } & \multirow{2}{*}{$\begin{array}{c}\text { Sample } \\
\text { (n) }\end{array}$} & \multirow{2}{*}{$\begin{array}{c}\text { Statem } \\
\text { ents }\end{array}$} & \multirow{2}{*}{$\begin{array}{l}\text { Max. } \\
\text { Score }\end{array}$} & \multicolumn{4}{|c|}{ Scores } & \multirow[b]{2}{*}{ 'F' Test } \\
\hline & & & & Mean & SD & $\begin{array}{c}\text { Mean } \\
(\%)\end{array}$ & $\begin{array}{l}\text { SD } \\
(\%)\end{array}$ & \\
\hline Government & 183 & 56 & 224 & 125.1 & 13.4 & 55.8 & 6.0 & \multirow{3}{*}{$733.32 * *$} \\
\hline Aided & 309 & 56 & 224 & 124.0 & 8.2 & 55.4 & 3.7 & \\
\hline Private & 328 & 56 & 224 & 166.2 & 20.5 & 74.2 & 9.2 & \\
\hline Combined & 820 & 56 & 224 & 141.1 & 25.5 & 63.0 & 11.4 & \\
\hline
\end{tabular}

** Significant at 1\% level,

Table-1 reveals overall mean scores of respondents on Practice of Health and Hygiene by Type of school. It was seen from the finding that mean practice scores were found highest in Private school (74.2\%) when compared to Government school (55.8\%) and Aided school (55.4\%) respondents. 
The data was analyzed statistically by using the $\mathrm{F}$ test and found that there was a highly significant difference between different types of school and the mean practice score on health and hygiene $(\mathrm{F}=733.32 * *)$.

TABLE 2 Aspect wise Overall Mean Practice Scores on Health \& Hygiene among School Children $\mathrm{N}=820$

\begin{tabular}{|c|c|c|c|c|c|c|c|}
\hline \multirow[b]{2}{*}{ No. } & \multirow[b]{2}{*}{ Aspects } & \multirow{2}{*}{$\begin{array}{c}\text { Statem } \\
\text { ents }\end{array}$} & \multirow{2}{*}{$\begin{array}{l}\text { Max. } \\
\text { Score }\end{array}$} & \multicolumn{4}{|c|}{ Scores } \\
\hline & & & & Mean & $\mathrm{SD}$ & Mean $(\%)$ & $\mathrm{SD}(\%)$ \\
\hline I & General Health & 13 & 52 & 37.8 & 5.8 & 72.7 & 11.2 \\
\hline II & Personal hygiene & 22 & 88 & 65.8 & 13.9 & 74.8 & 15.8 \\
\hline III & Environmental hygiene & 4 & 16 & 10.0 & 3.5 & 62.7 & 21.7 \\
\hline IV & Food hygiene & 6 & 24 & 11.2 & 6.3 & 46.5 & 26.2 \\
\hline $\mathrm{V}$ & Water hygiene & 6 & 24 & 3.8 & 1.5 & 15.8 & 6.2 \\
\hline VI & Dental \& Oral hygiene & 3 & 12 & 7.5 & 3.3 & 62.4 & 27.6 \\
\hline VII & Visual hygiene & 2 & 8 & 5.1 & 1.7 & 63.2 & 21.8 \\
\hline & Combined & 56 & 224 & 141.1 & 25.5 & 63.0 & 11.4 \\
\hline
\end{tabular}

Table -2 depicts the overall mean practice score on health and hygiene among school children. It was seen from the finding that overall mean practice scores were found to be 63.0 percent on health and hygiene. The mean practice scores were highest in the aspects of Personal hygiene $(74.8 \%)$ followed by General Health $(72.7 \%)$, Visual hygiene $(63.2 \%)$, Environmental hygiene (62.7\%) Dental and oral health (62.4\%), Food hygiene (46.5\%), and Water hygiene $(15.8 \%)$.

TABLE 3 Aspect wise comparison of Practice Scores on Health \&Hygiene among School Children $\mathrm{N}=820$

\begin{tabular}{|c|c|c|c|c|c|c|c|c|}
\hline \multirow{2}{*}{ No. } & \multirow{2}{*}{ Practice Aspects } & \multicolumn{6}{|c|}{ Respondents } & \multirow{2}{*}{ 'F' } \\
\cline { 3 - 8 } & & \multicolumn{2}{|c|}{ Government. } & \multicolumn{2}{|c|}{ Aided } & \multicolumn{2}{|c|}{ Private } & Test \\
\cline { 3 - 8 } & Mean & SD & Mean & SD & Mean & SD & \\
\hline I & General Health & 68.1 & 8.5 & 68.1 & 6.6 & 79.6 & 12.3 & $141.52^{* *}$ \\
\hline II & Personal hygiene & 65.4 & 12.3 & 65.7 & 10.3 & 88.5 & 11.2 & $419.00^{* *}$ \\
\hline III & $\begin{array}{c}\text { Environmental } \\
\text { hygiene }\end{array}$ & 52.8 & 17.0 & 51.7 & 15.0 & 78.7 & 19.6 & $228.97^{* *}$ \\
\hline IV & Food hygiene & 35.7 & 21.0 & 32.9 & 18.3 & 65.4 & 23. & $218.83^{* *}$ \\
\hline V & Water hygiene & 13.6 & 5.7 & 13.8 & 5.6 & 18.8 & 65.6 & $79.04^{* *}$ \\
\hline VI & $\begin{array}{c}\text { Dental \& Oral } \\
\text { hygiene }\end{array}$ & 55.6 & 30.1 & 51.7 & 29.4 & 76.3 & 16.0 & \multirow{2}{*}{$85.31^{* *}$} \\
\hline VII & Visual hygiene & 64.1 & 22.4 & 64.4 & 21.3 & 61.6 & 21.9 & $1.44^{\text {NS }}$ \\
\hline
\end{tabular}

** Significant at $1 \%$ level,

NS : Non-significant

Table 3 indicates the aspect wise comparison of practice scores on health and hygiene among school children. It was found that the children belonging to private school had good practice score towards Personal hygiene $(88.5 \%)$ followed by General health $(79.6 \%)$ and Environment hygiene $(78.7 \%)$ and Dental and oral hygiene $(76.3 \%)$ when compared to Government and Aided school children. Further, it was found that the children belonging to Private schools had moderate practice on Food hygiene (65.4\%) and Visual hygiene $(61.6 \%)$. It was also found from the mean practice score that the Government and Aided school children had a low practice of Food hygiene (32.9\%) and Water hygiene (13.8\%). 
The data was analyzed using F-test and found that there was a highly significant difference among different types of school on General health, Personal health, Water hygiene, Dental and oral hygiene, and Visual hygiene practices. It was also found that there was a nonsignificant difference among different types of school on Visual hygiene practices.

\section{CONCLUSION}

The overall mean practice scores were found to be 63.0 percent on health and hygiene the mean practice scores were found highest in Private school when compared to Government school and Aided school respondents. Children belonging to private school had good practice score towards Personal hygiene followed by General health and Environment hygiene and Dental and oral hygiene when compared to Government and Aided school children.

\section{REFERENCES}

[1] Asghar Syed Abid, Gupta Pratibha, SrivastavaMrinal R., Srivastava J. P., and ZaidiZeashan H. Health status of primary school children: study from a rural health block of Lucknow,International Journal of Community Medicine and public health, 4 (7),2017, pp 2498-2501

[2] S. Poongavanam, Rengamani, R. Srinivasan And Rajendra Prasad, Employee Welfare Measures \& Industrial Hygiene in Civil Construction Company - A Study, International Journal of Civil Engineering and Technology (IJCIET), Volume 8, Issue 7, Pp: 69-77.

[3] VivasAlyssa,BizuGelaye, NigusuAboset, AberaKumie, YemaneBerhane, and Michelle A. Williams, Knowledge, Attitudes, and Practices (KAP) of Hygiene among School Children in Angolela, Ethiopia, JPrev Med Hyg, 51(2),2010,pp 73-79.

[4] Syuhaida Idha Abd Rahim, Siti Khurshiah Mohd Mansor, Mohd Asmadi Yakob and Noraini Ismail, Food Safety, Sanitation and Personal Hygiene in Food Handling: An Overview from Islamic Perspective, International Journal of Civil Engineering and Technology, 9(9), 2018, pp. 1524-1530

[5] The Importance of Hygiene - India Parenting, Url www.indiaparenting.com > Health > General Health. 